\title{
A PEDAGOGIA - AO LONGO DOS TEMPOS
}

\section{Helena Gaspar ${ }^{1}$ \\ Célia Ribeiro ${ }^{2}$}

\begin{abstract}
Resumo: $O$ presente trabalho reporta todo um percurso civilizacional ancorado no desenvolvimento do professor. $\mathrm{Na}$ sequência deste estudo, foram retratados, numa perspetiva diacrónica, os vários contextos e as correntes educacionais que, em parte, assumem perenidade no pensamento e no agir atual. No entanto, a busca incessante do desenvolvimento da vida social destacou a figura do professor como o principal agente a quem são atribuídos inúmeros e diferentes papéis, progressivamente mais exigentes e complexos, em resultado da evolução da sociedade.

Do reverenciado estatuto de transmissor dos saberes, ele ocupa, na atualidade, uma função multifacetada, que lhe exige uma postura de contínuo questionamento e autorreflexão da sua praxis, no sentido de responder da forma mais eficaz ao aspeto basilar que é o sucesso das aprendizagens dos alunos. Neste seguimento, procura-se dar uma visão do que foi a pedagogia ao longo dos tempos, nomeadamente, na antiguidade oriental, clássica e cristã; passando pela idade média, moderna e Iluminismo e, por fim, na idade contemporânea.
\end{abstract}

Palavras-Chave: pedagogia, perspetiva histórica.

\section{Title: THE PEDAGOGY - THROUGHOUT THE TIMES}

Abstract: This paper reports to a whole civilizational journey anchored in the teacher's development. Following this study, the various contexts and educational currents that partly assume continuity in thought and action today were portrayed in a diachronic

\footnotetext{
${ }^{1}$;Professora de Português na Escola Secundária Alves Martins, Viseu; Mestre em Ciências da Educação pelo Departamento de Economia, Gestão e Ciências Sociais Centro Regional das Beiras da Universidade Católica Portuguesa, tendo sido orientada pelo segundo autor. Email: helmarper75@hotmail.com

2;Professora Auxiliar do Centro Regional de Viseu da Universidade Católica Portuguesa. Email: cribeiro@viseu.ucp.pt
} 
perspective. However, the relentless pursuit of the development of social life highlighted the figure of the teacher as the main agent to whom different and numerous roles are assigned, progressively more demanding and complex, due to the evolution of society.

From the revered status of the transmitter of knowledge, he occupies nowadays a multi-faceted position that requires him an attitude of continual questioning and self-reflection of his praxis, in order to respond most effectively to the fundamental aspect, which is the success of students' learning. In this context, the objective is to give an overview of what pedagogy has been throughout history, particularly in the eastern, classical and Christian antiquity; during the middle, modern and Enlightenment ages and, finally, the contemporary age.

Keywords: pedagogy, historical perspective.

\section{A PEDAGOGIA - AO LONGO DOS TEMPOS}

\subsection{A pedagogia - o reflexo de uma cultura ancestral.}

Neste artigo, pretende-se demonstrar a forma como a pedagogia foi sempre uma área do saber de extremo valor no percurso civilizacional e que esteve sempre sujeita à influência dos fatores económicos, sociais, políticos e culturais.

É de destacar que, mesmo nas sociedades mais remotas, a "escola" esteve sempre ao serviço da organização social de uma determinada comunidade, sendo, por isso, o reflexo de uma cultura ancestral que, em determinados momentos, conheceu ruturas e, com elas, a necessidade da mudança.

De seguida, serão descritos, sucintamente, os vários contextos, as correntes educacionais ao longo da história.

Na Antiguidade Oriental, a invenção da escrita e a sua importância levou a que surgissem as primeiras escolas que tinham como objetivo formar escribas. Esta ocorrência dá-se, primeiramente, na Suméria (Mialaret \& Vial, 1985, pp. 38-57).

O processo educativo estava entregue à classe sacerdotal, nos templos, e o caráter religioso percorria todas as matérias. Além das matérias académicas, havia uma intensa preparação militar. Gal (1979) e Marques (2001) referem que apenas os filhos dos sacerdotes e da aristocracia tinham acesso à escola e a formação de um escriba "ia desde os sete anos até aos vinte e poucos anos" (Marques, 2001, p. 12). A metodologia passava pela obediência à autoridade, pela memorização dos textos 
canónicos, pela repetição das tarefas e pela utilização de castigos físicos para reforço das aprendizagens.

A grandeza e a dimensão do Império Egípcio podem ser apontadas como sendo fatores para o ensino ter-se alargado, pois havia uma imperiosa necessidade de formar escribas e funcionários para a administração pública. A partir de 3000 a. C., encontra-se três tipos de escolas (Marques, 2001, p. 12): as escolas dos templos (formação de sacerdotes); as escolas da corte (formação dos altos funcionários) e as escolas espalhadas pelas províncias (formação de funcionários e escribas para a administração local e os negócios privados).

Ainda na antiguidade (Gal, 1979; Marques, 2001), o povo hebreu considerava a família, estruturada na figura dominante do pai, de acordo com a tradição das civilizações do Médio Oriente Antigo, como sendo primeira "escola". A par da família, a influência dos vizinhos e das companhias também era valorizada no desenvolvimento das crianças. Os conhecimentos tinham uma função unificadora de determinado povo ou tribo que, por norma, era nómada. Portanto, a transmissão oral da sabedoria era um ato continuado e adquiria-se através do exercício da memória e a sua aprendizagem realizava-se através da audição atenta dos mestres que, quando necessário, faziam apelo à correção, repreensão e aos castigos. A educação, inseparável da teologia e da religião, pertencia à família e às sinagogas. Segundo Gal (1979), "os professores das classes elementares recebiam muitas vezes presentes ou uma gratificação, ou então, para poderem viver, exercem uma outra profissão" (p.32). Esta era uma forma criteriosa de certificar ou graduar indivíduos que pretendiam um determinado cargo público.

Como é referido na História Mundial da Educação I (Mialaret \& Vial, 1985), na China, no século V a. C., a educação tinha como principais objetivos a aprendizagem da escrita e o desenvolvimento do caráter que Confúcio $^{3}$ demonstrou, de forma sucinta, com "Analectos", ser a sabedoria chinesa e o ideal do homem educado. Um dos aspetos originais da educação chinesa era o seu caráter meritocrático que punha à prova todos os estudantes e estes eram distinguidos e escolhidos mediante as capacidades demonstradas através da realização de exames.

\footnotetext{
${ }^{3}$ Confúcio: filósofo chinês (551 a.C. - 479 a.C.).
} 
Na Antiguidade Clássica, embora ambas polis ${ }^{4}$ ou cidades-estado gregas, Esparta e Atenas eram muito distintas em relação à forma como concebiam o sistema educativo.

Em Esparta, o processo educativo era militarista despótico, pois visava responder ao estado de guerra permanente. A criança que, poucos dias depois de nascer, era examinada por um conselho de anciãos que decidia se ela devia viver ou morrer, era considerada propriedade do estado e, desde muito cedo (a partir dos sete anos), era posta ao cuidado de uma escola oficial que a preparava para se tornar um bom soldado.

Em Atenas, embora houvesse também o costume de expor a criança doente ou com deficiência até à morte, essa decisão era da responsabilidade dos progenitores e não do conselho de anciãos. $\mathrm{O}$ sistema educativo apontava para um harmonioso equilíbrio das disciplinas de caráter físico (ginástica, corrida, salto, natação, luta livre e arremesso do dardo e do disco) e das disciplinas de caráter intelectual (o desenho, a geometria, a música, a leitura, a escrita e a gramática).

Como reflexo da sociedade, o sistema educativo, na sociedade ateniense, principalmente com Péricles ${ }^{5}$, foi estruturado de forma a ir ao encontro das exigências inerentes ao regime democrático. A participação, a afirmação e a ascensão na política passava por uma formação centrada nas disciplinas utilitárias, ou seja, na retórica, na gramática, na etimologia e na sintaxe. Neste contexto, os sofistas ${ }^{6}$ tiveram um papel preeminente ao preparar os jovens para este novo ideal político.

Marques (2011) refere que Sócrates ${ }^{7}$ e Platão ${ }^{8}$ opuseram-se ao utilitarismo e ao relativismo ético da educação dados pelos sofistas. Os referidos filósofos da antiguidade clássica defendiam e concebiam a aquisição do conhecimento e do autoconhecimento através de processos incitadores da maiêutica, dedutivos e demonstrativos da dialética. Salienta--se que, embora diretamente não visassem uma preparação

\footnotetext{
${ }^{4}$ Polis: cidade, em grego.

${ }^{5}$ Péricles (461-429): líder político e militar de Atenas, na Grécia, do século V a. C. Pode atribuir-se-lhe, em larga medida, o desenvolvimento do sistema democrático ateniense, bem como o lugar de destaque que a cidade-estado ocupou naquela região. (Infopédia [Em linha]. Porto: Porto Editora, 2003-2013. [Consult. 2013-08-08].)

6 Os sofistas correspondem à conceção mais atual de professor, sendo mesmo considerados como os primeiros professores na história. Estes, a troco de dinheiro, ensinavam a virtude, a aretê ou, como também lhe chamam, a technê (técnica, ofício, habilidade, arte ou saber aplicado) política.

${ }^{7}$ Sócrates (469 a. C. - 399 a. C.): filósofo grego.

${ }^{8}$ Platão (427 a. C. - 347 a.C.): filósofo grego.
} 
profissional, estes ideais pedagógicos foram importantes no que se refere à construção do pensamento crítico e à busca permanente do conhecimento e da verdade.

Mais tarde, Aristóteles ${ }^{9}$, no século IV a. C., no Tratado da Política (2000, pp.50-64), enfatizou a educação como sendo a essência na manutenção de um governo. Ainda, na referida obra, no capítulo "Do Eugenismo e da Educação" (pp.50-69), o filósofo atribuiu preceitos a ter em conta nos procedimentos educativos, ou seja, era importante agir de acordo com a idade, o sexo e a condição social. O Homem, "animal político", segundo Aristóteles, pertencia ao estado e, como tal, deveria haver mecanismos/cuidados que zelassem desde o momento do seu nascimento. Era essencial respeitar a "marcha da natureza", pois esta "(...) só esboçou as suas obras. A obra da educação, como de todas as artes, deve unicamente suprir o que falta ao seu ser" (p. 59).

Cícero $^{10}$, personalidade que ocupou o mais alto cargo da República Roma, o de cônsul, defendeu uma educação direcionada para os interesses da pátria, ou seja, esta deveria ter um caráter utilitário e, tal como Aristóteles, considerava o homem um animal político.

Quintiliano $^{11}$ também deixou uma extensa obra intitulada $D e$ Institutione Oratoria, o primeiro tratado dedicado exclusivamente à educação. Num traço inovador para a sua época, Quintiliano condenou os castigos físicos; defendeu que a criança deveria frequentar o mais cedo possível a escola; referiu a necessidade de identificar os talentos e as diferenças individuais e a adoção de procedimentos diferenciados no ensino.

A obra $O$ Pedagogo de Clemente de Alexandria ${ }^{12}$ demonstra a preocupação do autor (posteriormente convertido ao cristianismo em Alexandria) em conciliar o estudo da filosofia com os preceitos da religião. Marques (2001, p. 40) refere que a filosofia era "entendida como um instrumento ao serviço da fé, ou como escrava da teologia".

\footnotetext{
${ }^{9}$ Aristóteles (384 a.C. - 322 a. C.): filósofo grego, juntamente com Sócrates e Platão, é visto como um dos fundadores da filosofia ocidental.

${ }^{10}$ Marco Túlio Cícero (106 a. C. - 43 a. C.): filósofo, orador, escritor, advogado e político romano.

11 Marco Fábio Quintiliano (35 d.C. - 96 d.C.): professor de retórica, filólogo conceituado e advogado. Recebeu toda a sua educação em Roma, onde mais tarde abriu uma escola de Retórica. Foi o primeiro professor a ser pago pelo Estado.

12 Clemente de Alexandria ou Tito Flávio Clemente (150-215): escritor, teólogo, apologista e mitógrafo cristão grego nascido em Atenas.
} 
Na Antiguidade Cristã, século III ao século XIV, à medida que o império romano sucumbia e os povos bárbaros rapidamente se convertiam ao cristianismo, o clero passou a ter o domínio na educação.

Este contexto socialmente conturbado e fragmentado fomentou a mentalidade do homem medieval que, sendo profundamente religioso, buscava, durante a vida terrena, a salvação e a felicidade eterna. Os mosteiros passaram a ser as estruturas físicas que preservavam a cultura clássica e, através da atividade dos copistas, também a ampliavam.

Orígenes ${ }^{13}$ surge associado aos primeiros católicos que foram perseguidos e, no ensino, contribuiu para a divulgação desta nova doutrina. Desde muito cedo, dedicou-se ao ensino, tendo sido responsável pela escola catequética de Alexandria que dirigiu durante trinta anos. Deixou numerosas obras, entre estas, destacam-se: Doutrina Verdadeira, Sobre os Dozes Profetas e Comentários ao Evangelho de São Mateus. Os seus textos evidenciam uma preocupação no que respeita à educação das crianças que, segundo este, deveria basear-se no ensino da catequese, no ensino dos textos bíblicos e na aprendizagem da gramática.

Vultos eminentes deste período foram também São Basílio ${ }^{14}$ e São João Crisóstomo ${ }^{15}$ que dedicaram as suas vidas a consolidar o ideal cristão. O primeiro, advertindo para o perigo do estudo da cultura clássica, dedicou parte dos seus escritos à educação moral e à aquisição da virtude. O segundo, São Crisóstomo, na sua obra Sobre a Vanglória e a Educação, referiu a importância da educação dada pelos pais aos seus filhos, fundamentalmente o papel da mãe que passava mais tempo com eles. A linha de pensamento deste religioso pautava-se pela defesa da superioridade da vida monástica face à vida mundana. De forma a exemplificar a sua conceção de educação, criou a conhecida alegoria

${ }^{13}$ Orígenes (185-253): cognominado Orígenes de Alexandria ou Orígenes de Cesareia ou ainda Orígenes o Cristão, foi um teólogo, filósofo neoplatónico patrístico e é um dos Padres gregos.

14 S. Basílio (329-379): “ (...) bispo e doutor da Igreja, nasceu na Capadócia (Turquia) (...). Depois de estudar em Constantinopla (...) decidiu seguir a vida monástica, não só tornando-se monge em Anesos, nas margens do rio Íris, no Ponto, mas também desenvolvendo e organizando "Regras" da vida ascética." Infopédia [Em linha]. Porto: Porto Editora, 2003-2013. [Consult. 2013-08-15].

15 São João Crisóstomo (347-411): teólogo e escritor cristão, arcebispo de Constantinopla no fim do século IV e início do V. Sua deposição em 404 produziu uma crise entre a Santa Sé e a Sé Patriarcal. Pela sua inflamada retórica, ficou conhecido como Crisóstomo (que em grego significa «boca de ouro»). 
sobre as cinco portas, ou seja, as cinco entradas do bem e do mal: a língua, o ouvido, o olfato, os olhos e o tato.

Marcante pelo seu pensamento foi Santo Agostinho ${ }^{16}$, sob o ponto de vista pedagógico, retomou as teorias de Platão ao referiu que conhecer era recordar e aprender era descobrir as verdades eternas que cada um possui. No livro da sua autoria intitulado De Magistro, o autor explicou a função do professor que não era a transmissão da verdade, pois só Deus é que a detinha, mas sim o papel de facilitador da descoberta do conhecimento interior. No fundo, a distinção que fez entre o papel do professor e o do aluno foi a superioridade que o primeiro tinha em suscitar e motivar na procura da verdade interior que se processava através da contemplação.

Nos Finais da Idade Média, entre o século XII e o XV que Marques (2001, p. 67) denomina "o crepúsculo da Idade Média", deram-se importantes transformações a nível intelectual que iriam alicerçar o pensamento moderno.

No século XII, um dos intelectuais cristãos importantes por defender o uso da razão na procura do conhecimento é Pedro Abelardo ${ }^{17}$. Rompendo com a tradição neoplatónica até então dominante, Abelardo pretendeu ensinar que o conhecimento intelectual se realizava por abstração, penetrando nas próprias coisas pelos sentidos. Foi considerado grande mestre da dialética e intelectual do espírito lógico e da clareza racional.

Ao pedagogo Hugo de São Vitor ${ }^{18}$ deve-se a primeira sistematização do processo educativo na era feudal e o primeiro grande tratado de didática e pedagogia medieval intitulada Didascalião. Ainda na mesma linha de pensamento de Santo Agostinho, este autor considerou que a tarefa do educador consistia em levar progressivamente o aluno a passar do mundo sensorial, que dava acesso ao conhecimento secular, para o mundo sobrenatural, onde residia a verdade divina, imutável e eterna. A reflexão filosófica era o meio de alcançar a sabedoria.

\footnotetext{
${ }^{16}$ Aurélio Agostinho, dito de Hipona: conhecido como Santo Agostinho (Tagaste, 13 de novembro de 354 - Hipona, 28 de agosto de 430), foi bispo, escritor, teólogo, filósofo e é um Padre latino e Doutor da Igreja Católica.

17 Pedro Abelardo (1079-1142): foi um filósofo escolástico francês, um teólogo e grande lógico. É considerado um dos maiores e mais ousados pensadores do século XII. ${ }^{1}$ Ficou conhecido do público por sua vida pessoal e o relacionamento com Heloísa, de que fala em sua História das Minhas Calamidades.

${ }^{18}$ Hugo de São Vitor (1096-1141): filósofo, teólogo e autor místico da Idade Média. Foi também um importante professor da escola da abadia de São Vitor, em Paris, tendo recebido seu nome por isso.
} 
O eminente católico John de Salisbury ${ }^{19}$, ao beber os ideais grecoromanos, inicia um movimento humanista cristão. Este relevou a função do bom educador para uma pessoa do clero, pois reunia elementos morais, éticos, intelectuais, sociais e espirituais para o desenvolvimento desta tarefa. Dedicada à educação deixou a obra intitulada Metalogicon. Para além da dialética e da retórica, considerou importante o estudo da lógica, da gramática, da aritmética, da geometria, da astronomia e da música.

Incontornável personalidade foi São Tomás de Aquino $^{20}$. Este considerou a educação como sendo uma via para obter a felicidade, ou seja, a educação deveria preparar o homem para merecer a vida eterna. "Faz o bem e evita o mal" foi a sua máxima, aplicável a todos os humanos, independentemente da cultura e do tempo. Com a sua obra, Summa de Theologica, Tomás de Aquino escreveu um conjunto de definições de padrões morais e de conselhos práticos que tiveram uma presença constante na sociedade do século XIII. Esta sumidade do clero contribuiu em grande escala para a organização e orientação das pequenas comunidades naturais como a família que, por sua vez, tinha por principal finalidade a procriação e a educação dos filhos.

Os literatos Dante ${ }^{21}$, Petrarca ${ }^{22}$ e Boccaccio $^{23}$ defenderam o estudo dos clássicos gregos e romanos, do vernáculo, para além do greco e do latim e da criação de uma literatura nacional.

Relativamente à Idade Moderna, Garin (1972), na obra $O$ Renascimento, história de uma revolução cultural, clarifica que o termo "Renascimento" é, antes de tudo, "uma manifestação de cultura, uma

${ }^{19}$ John Salisbury (1110-1180): foi considerado um dos mais brilhantes pensadores do seu tempo. Ao longo da sua vida desempenhou importantes cargos no seio da Igreja Católica. Foi também autor de importante pensamento político, registado em obras como Policraticus ou Metalogicon, assim como teorizador do ensino.

20 Tomás de Aquino (1225? -1274): padre dominicano, filósofo, teólogo, distinto expoente da escolástica, proclamado santo e Doutor da Igreja cognominado Doctor Communis ou Doctor Angelicus pela Igreja Católica.

${ }^{21}$ Dante Alighieri (1265-1321): escritor, poeta e político italiano. É considerado o primeiro e maior poeta da língua italiana, definido como il sommo poeta. Autor da obra-prima A Divina Comédia.

${ }^{22}$ Francesco Petrarca (1304-1374): intelectual, poeta e humanista italiano, famoso, principalmente, devido ao seu romanceiro. É considerado o inventor do soneto, tipo de poema composto de 14 versos.

${ }^{23}$ Giovanni Boccaccio (1313-1375): poeta e crítico literário italiano, especializado na obra de Dante Alighieri. 
conceção da vida e da realidade que impregna as artes, as letras, as ciências, os costumes" (p. 14). Foi em Itália que surgiram as "novas escolas" que, para além dos ensinamentos literários e morais, visavam uma formação geral do cidadão.

Arenilla e colaboradores (2013) referem que Erasmo ${ }^{24}$ fez parte dos intelectuais humanistas que pugnaram o método escolástico nas universidades. No âmbito da educação, exerceu grande mérito enquanto precetor do Arquiduque Carlos da Áustria, futuro imperador Carlos V. Na obra Institutio principis Christiani, em 1516, Erasmo demonstrou a preocupação de inculcar, no futuro rei, o sentido de Estado, ou seja, zelar pelo bem-estar do seu povo, mesmo que isso sacrificasse a sua vida privada. Definiu ainda o bom professor como sendo aquele que se interessava por cada aluno, conhecendo-lhe a personalidade. Este deveria dominar bem as matérias, ter boa capacidade de comunicação e possuir virtudes morais. Importante referir que Erasmo foi pioneiro na defesa da educação infantil.

Tomás Morus ${ }^{25}$, na obra Utopia, em 1516, expressou o seu ideal de sociedade perfeita e em relação ao processo de ensino e aprendizagem focalizou a prática estudo/aprendizagem como sendo um dever e um direito que se estendia a todos os cidadãos, incluindo as mulheres.

Francis Bacon $^{26}$ (Arenilla et al, 20013), embora não tenha sido pedagogo, trouxe uma nova conceção do processo educativo e surge evidente nas suas três obras: The advancement of Learning, em 1605, Novum Organum, em 1620, e New Atlantis, em 1624. A sua originalidade, isto numa época em que o ensino continuava a ser livresco, repetitivo e memorizante, incide na defesa de um método mais indutivo para a investigação e descoberta da verdade.

A descrição de uma utopia é, sem dúvida, a consubstancialização de ideais e, tal como em Utopia e New Atlantis, na Civitas solis, em 1623, de

${ }^{24}$ Erasmo de Roterdão (1466-1536): doutorou-se na Universidade de Bolonha e, embora tenha seguido a vida religiosa, destacou-se sobretudo como humanista, filósofo e pedagogo.

25 Tomás Morus (1478-1535): homem de estado, diplomata, escritor, advogado e homem de leis, ocupou vários cargos públicos, e em especial, de 1529 a 1532, o cargo de Chanceler do Reino de Henrique VIII da Inglaterra. Foi condenado à pena capital, em 1535, por ter criticado o divórcio e o novo casamento do rei.

${ }^{26}$ Francis Bacon (1561-1626): político, filósofo e ensaísta inglês, barão de Verulam, visconde de Saint Alban. É considerado como o fundador da ciência moderna. 
Campanella ${ }^{27}$, o processo educativo era um aspeto de primeira importância na sociedade perfeita idealizada.

$\mathrm{Na}$ Alemanha, a reforma também veio apelar a uma mudança no modo de vida dos cristãos e foi Melanchthon ${ }^{28}$ que pôs em prática e impulsionou uma reforma educativa baseada na doutrina protestante. Este humanista teve um papel preponderante na formação de professores e na criação de escolas protestantes. A principal diferença em relação ao currículo das escolas católicas estava na maior ênfase concedida à matemática e às ciências pelas escolas protestantes. A outra diferença consistia no facto de as novas escolas pertencerem às municipalidades, embora as igrejas locais protestantes estivessem sempre representadas nas direções.

A influência dos reformistas Alstedius ${ }^{29}$ e Andreae ${ }^{30}$ na pedagogia, na Alemanha, incidiu, fundamentalmente, na defesa de uma escola universal diferenciada.

Tendo recebido influências dos dois pedagogos referidos, Comenius ${ }^{31}$ (Arenilla et al, 20013) desenvolveu, ao longo de toda a sua vida, um trabalho notável, no sentido de tornar o ensino um bem público, universal. Na sua obra Didactica Magna, em 1621-1657, o autor apresenta um método de "ensinar tudo a toda a gente", prevalecendo ainda hoje como uma referência no processo de ensino que aponta essencialmente para um ensino que respeita as diferentes etapas do desenvolvimento psicológico do aluno; que se baseia na observação e na experiência sensorial; que não restringe $o$ acesso à escola, independentemente do sexo, da condição social ou económica, todos têm os mesmos direitos; que concebe que a aprendizagem deve partir do mais simples para o mais complexo e que deve haver um equilíbrio entre o estudo e o divertimento.

\footnotetext{
${ }^{27}$ Giovanni Domenico Campanella (1568-1639): filósofo renascentista italiano, poeta e teólogo dominicano.

28 Philipp Melanchthon (1479-1560): foi um reformador alemão. Colaborador de Lutero, redigiu a Confissão de Augsburgo e converteu-se no principal líder do luteranismo após a morte do próprio Lutero.

29 Johann Heinrich Alstedius (1588-1638): filósofo, teólogo protestante e escritor alemão, autor de uma enciclopédia.

${ }^{30}$ Johann Valentin Andreae (1586-1654): teólogo alemão.

${ }^{31}$ Iohannis Amos Comenius (1592-1670): bispo protestante da Igreja Moraviana, professor, cientista e escritor checo, considerado o fundador da didática moderna.
} 
Por sua vez, a pedagogia dos jesuítas ${ }^{32}$ surge no contexto cultural da contra reforma e o seu impacto foi de tal forma significativo que, presentemente, o seu ideário pedagógico permanece em muitas escolas católicas (Gal, 1979, Marques, 2001). Adotando a máxima "a educação das crianças é a renovação do mundo", os jesuítas tentaram difundir os conhecimentos necessários a um cristão. A disciplina, que sustentava um ambiente de respeito, ordem e hierarquia, era salvaguardada pelos professores que exerciam diferentes cargos para esse fim. A preservação do ambiente ordeiro e respeitador da hierarquia fazia com que raramente fossem aplicados castigos. Outro aspeto merecedor de relevo foi a preocupação da Companhia de Jesus relativamente à formação contínua dos seus professores, criando, assim, uma publicação periódica denominada "Diário".

A rutura com o ensino escolástico passava pela crítica ao ensino repetitivo e memorizante que Michel Montaigne ${ }^{33}$ (Arenilla et al, 2013) evidenciou n'Os Ensaios (1580 - 1588). Para o autor, como refere Gal (1979, p. 67), a educação tinha como principal fim a promoção da inteligência dos alunos, pois considerava inútil o saber sem 0 entendimento. Apologista da individualização do ensino e da utilização do método socrático, defendia que o professor deveria levar ou ajudar o aluno a descobrir. Tal como outros humanistas, não deu só primazia à educação intelectual, mas também considerou importantes a educação física e a educação do caráter. Na metodologia refutou e censurou os castigos corporais.

Entidade coletiva e não menos importante no contexto da reforma foram as "Petites Écoles" ou as "escolinhas" de Port-Royal ${ }^{34}$. A sua pedagogia incidia essencialmente no estudo das humanidades, embora não descurasse as ciências, como refere Marques (2001). Conceção elitista e muito seletiva do ensino, pois só os alunos da nobreza e da

32 A Companhia de Jesus, cujos membros são conhecidos como jesuítas, é uma congregação religiosa fundada em 1534 por um grupo de estudantes da Universidade de Paris, liderados pelo basco Íñigo López de Loyola, conhecido posteriormente como Inácio de Loyola. A Congregação foi reconhecida por bula papal em 1540. É hoje conhecida principalmente por seu trabalho missionário e educacional.

33 Michel Montaigne (1533-1592): político, filósofo, escritor e cético francês, considerado como o inventor do ensaio pessoal.

${ }^{34}$ Petites écoles de Port-Royal (em português: Escolinhas de Port-Royal): escolas que utilizavam um sistema de ensino estabelecido em 1637 pelos intelectuais que se reuniram em Port-Royal-des-Champs, na metade do século XVII, no auge da controvérsia Jansenista. Estas funcionaram até 1660. 
burguesia é que frequentavam estas escolas, estava estritamente ligada à forma como os jansenistas viviam a sua espiritualidade, ou seja, só alguns homens estavam predestinados a obter o sucesso.

O filósofo Locke ${ }^{35}$ (Arenilla et al, 20013) deixou uma obra intitulada Some Thoughts Concerning Education, em 1692, que preconizou o conceito de formação profissional ao longo da vida para as pessoas da classe trabalhadora que estavam no desemprego.

Paulatinamente, a distinção entre a educação e a instrução tornou-se visível em alguns autores desta época. Rollin ${ }^{36}$, na sua obra intitulada Traité des Études, em 1726-31, referiu que a instrução era a o cultivo do espírito empírico e o desenvolvimento da cultura geral e a educação era mais complexa, uma vez que procura formar o caráter dos homens.

No Iluminismo, o desenvolvimento económico e social, que caraterizou o século XVIII, trouxe uma nova visão e postura perante o crescimento do ser humano, e esteve, por sua vez, relacionado com o Movimento Iluminista, associado à crença do poder da razão e do progresso da civilização humana. Por conseguinte, a escola passou a se encarada como um recurso incontornável e inerente à desejada libertação do próprio homem através do conhecimento racional e experimental.

Helvetius ${ }^{37}$, como a maioria dos teóricos da sua época, era materialista e empirista. Considerou que os homens nasciam iguais e as diferenças posteriores eram fruto da realidade envolvente e da educação. Segundo este, a educação ditava a evolução do homem. Este distinguiu a educação espontânea, que era o resultado das circunstâncias e das paixões, da educação intencional, que era planificada e obedecia a um método e sequência precisa.

No âmbito da pedagogia, Rousseau ${ }^{38}$ (Arenilla et al, 20013) deixou o tratado educacional denominado Émile, em 1762, cuja influência foi sentida nos séculos seguintes, permanecendo ainda hoje como uma fonte

35 John Locke (1632-1704): filósofo inglês e ideólogo do liberalismo, sendo considerado o principal representante do empirismo britânico e um dos principais teóricos do contrato social.

${ }^{36}$ Charles Rollin (1661-1741): historiador francês, professor de retórica e reitor na universidade de Paris.

37 Claude Adrien Helvetius (1715-1771): filósofo e literato francês e um dos enciclopedistas, que marcaram a geração da Revolução Francesa. Considerado um radical materialista, foi o principal pensador do utilitarismo, na linha de John Locke.

38 Jean-Jacques Rousseau (1712-1778): filósofo, teórico político, escritor e compositor autodidata suíço. É considerado um dos principais filósofos do iluminismo e um precursor do romantismo. 
de inspiração às reformas educativas e aos modelos pedagógicos não diretivos e libertários. Sucintamente, este defendeu uma educação livre de imposições e constrangimentos.

O principal contributo de Pestalozzi ${ }^{39}$ reside fundamentalmente na democratização do ensino, ao criar escolas para crianças desfavorecidas e abandonadas.

Marques (2001) alude que, na mesma linha teórica de Rousseau, é de referir os contributos de Humboldt ${ }^{40}$ e de Fröbel $^{41}$. O primeiro, no âmbito dos estudos universitários, enfatizou a cultura geral, recusando o ensino especializado ou profissionalizante e defendeu um ensino baseado na investigação pelo aluno, dispensando, tanto quanto possível, a direção do professor. O segundo, na educação das crianças de um a sete anos de idade, desenvolveu um espaço onde a criança se pudesse envolver na atividade criativa: o jardim de infância (Arenilla et al, 20013).

No ensino universitário, fundamentalmente na formação de futuros professores, Herbart ${ }^{42}$ expressou diferenças relativamente aos teóricos acima referidos no que respeita essencialmente à metodologia pedagógica. Este considerou que o processo educativo incluía três etapas: o governo, que consistia no imprescindível controlo do professor, admitindo a coação, os castigos e os prémios; a disciplina, no desenvolvimento do caráter do aluno (o aspeto central na pedagogia de Herbart); e a instrução, que não se resumia à acumulação de informação e conhecimentos, mas à junção das outras etapas.

A Idade contemporânea, século XX, caracterizou-se por ser um período de contrastes, de conflitos e de instabilidade. Foi neste mesmo século que ocorreram as duas guerras mais mortíferas e destruidoras da humanidade. A nível do pensamento, da cultura e da educação houve profundas revoluções: Freud, com a psicanálise, alterou a conceção clássica do indivíduo; o emergir dos irracionalismos políticos e económicos, que se traduziram com devastadores regimes totalitários; a nível cultural, o surrealismo. Outro aspeto que se impôs foi a

39 Johann Heinrich Pestalozzi (1746-1827): pedagogo suíço e educador pioneiro da reforma educacional.

40 Wilhelm Von Humboldt (1767-1835): pedagogo, filósofo, linguista e político alemão.

${ }^{41}$ Friedrich Wilhelm August Fröbel (1782-1852): pedagogo alemão com raízes na escola Pestalozzi. Foi o fundador do primeiro jardim de infância.

42 Johann Friedrich Herbart (1776-1841): foi um filósofo, psicólogo, professor alemão, fundador da pedagogia como disciplina académica. 
globalização, facilitada pelo avanço das tecnologias e, sequencialmente, pelos meios de comunicação.

Modelos educacionais associados às novas conceções, métodos e currículos surgiram numa tentativa de responder aos novos paradigmas sociais.

Marques (2001) refere que Dom Bosco $^{43}$ e o Padre Usera ${ }^{44}$ desenvolveram uma obra dedicada às crianças pobres e desprotegidas. Este processo educativo baseava-se na razão, na religião e na amabilidade e num ambiente familiar, alegre e cordial, longe de "burocracias e de projetos impostos e artificiais". Os professores eram considerados como amigos mais velhos e mais sapientes. Na mesma linha de pensamento e de ação, Padre Usera sobrevalorizou o papel da afetividade e a frase que sintetizou o seu ideal foi: "Educar no, por e para o amor".

Marques (2001) refere que a pedagogia social é um aspeto relevante em Natorp ${ }^{45}$ e em Durkheim ${ }^{46}$. Para ambos, a educação tinha por objeto a cultura e toda a cultura era comunitária,

O pedagogo Kerschensteiner ${ }^{47}$, segundo Marques (2001), percursor da escola ativa e das escolas profissionais, defendeu uma pedagogia global e ampla, ou seja, para além da escola, referiu outras instituições com valor educativo, por exemplo: museus, associações culturais, mass media... Também estabeleceu a distinção entre as escolas de cultura geral e as escolas profissionais; as primeiras visavam a formação de trabalhadores intelectuais e as segundas formavam diversos profissionais essenciais à sociedade. Para este, a ação pedagógica era um ato de compreensão, um ato de amor e um ato teórico.

O modelo pedagógico, cuja ideia basilar é a democracia, criado pelo filósofo pragmatista Dewey ${ }^{48}$, centrou-se nos princípios da atividade da criança, da utilidade e da união dos meios e dos fins. Nesta perspetiva,

43 João Melchior Bosco (1815-1888): sacerdote católico italiano, fundador da Pia Sociedade São Francisco de Sales e canonizado em 1934.

${ }^{44}$ Mariano Nicomedes Usera y Alarcón (1890-189): religioso e missionário, fundador das Irmãs do Amor de Deus e da Sociedade Protetora dos Meninos da Ilha de Cuba.

${ }^{45}$ Paul Gerhard Natorp (1854-1924): filósofo e pedagogo alemão.

${ }^{46}$ Émile Durkheim (1858-1917): considerado um dos pais da Sociologia tendo sido o fundador da escola francesa, posterior a Marx, que combinava a pesquisa empírica com a teoria sociológica.

47 Georg Michael Kerschensteiner (1854-1932): pedagogo alemão. Discípulo de Pestalozzi, foi um dos criadores das escolas do trabalho. Fundou uma pedagogia que valoriza a inteligência prática, em oposição ao intelectualismo de Herbart.

${ }^{48}$ John Dewey (1858-1952): filósofo e pedagogo americano. 
era valorizada apenas a aprendizagem que fosse útil para a criança e a escola traduzia-se num microcosmos onde professores e alunos se responsabilizavam pelo seu autogoverno.

Formados em medicina, Maria Montessori ${ }^{49}$ e Ovide Decroly ${ }^{50}$ (Arenilla et al, 20013), que inicialmente se interessaram pela educação das crianças com deficiência, desenvolveram e aplicaram ideias pedagógicas a todas as crianças. No entanto, há que destacar diferenças, sendo uma delas a função do professor. No primeiro ideário, o professor seria mais um recurso do que transmissor de informações e de instruções; no segundo, a educação da criança era construída através de uma visão global proporcionada não só pela escola ou pelos professores de forma isolada, mas por todo o meio físico e social de que faz parte, sendo o lema "a escola pela vida, para a vida".

Impulsionador da pedagogia funcional, Claparède ${ }^{51}$ defendeu uma escola ativa, mais parecida com um laboratório do que um auditório, onde o jogo e a atividade lúdica predominavam. Visto que nesta conceção o desenvolvimento da criança estava associado a processos particulares de adaptação ao meio e de resolução de problemas, a escola deveria estimular o exercício, a motivação interior e a autodisciplina.

O filósofo Alain ${ }^{52}$ defendeu uma metodologia baseada no rigor, sem divertimento, nem jogo. Para este a educação era uma forma de libertação do homem da barbárie primitiva e uma via da consciencialização do seu poder para se governar e para obter um saber comprovado. Refutou a individualização do ensino e a diferenciação curricular, considerando que o mais importante não era nivelar os alunos, mas fazer com que cada um atingisse o seu máximo.

Evidenciando o seu contexto histórico-social, $\mathrm{Kriek}^{53}$ teorizou uma pedagogia ao serviço de uma política totalitária e discriminatória. Nesta

49 Maria Montessori (1870-1952): educadora, médica, católica e feminista italiana conhecida pelo método educativo que desenvolveu.

${ }^{50}$ Jean-Ovide Decroly (1871-1932): médico, professor e psicólogo belga.

51 Édouard Claparède (1868-1952): neurologista e psicólogo do desenvolvimento infantil, que se destacou pelos seus estudos nas áreas da psicologia infantil, da pedagogia e da formação da memória.

52 Émile-Auguste Chartier (1868-1951): o pseudónimo literário era Alain, foi um jornalista, ensaísta e filósofo francês.

${ }^{53}$ Ernest Krieck (1882-1947): pedagogo e considerado um dos pensadores alemães mais representativos do nacional-socialismo, tendo, na vigência deste regime, exercido o alto cargo de reitor da Universidade de Heidelberga. Das suas obras 
conceção, a escola, que tinha por objetivo reforçar a imperiosa renovação social, contribuía para a dissolução do indivíduo no Estado.

Um dos nomes sonantes foi, segundo Damião (2010) e Marques (2001), Alexandre Neill ${ }^{54}$, apologista da escola em que era a vontade do aluno que predominava, de um ensino que se distanciava das convenções, obrigações e constrangimentos das instituições sociais, económicas, religiosas e políticas.

Marques (2001) refere que a "união entre trabalho, instrução intelectual, exercício físico e treino politécnico elevará a classe operária" é a máxima da pedagogia marxista regida por princípios práticos e utilitários. Inserida na superestrutura, que é a sociedade, a educação é um elemento essencial na medida em que assegura e perpetua o comunismo.

Numa outra perspetiva de ensino, Freinet ${ }^{55}$ ao criticar o intelectualismo, o abstracionismo e o racionalismo excessivo da escola tradicional, valorizou a espontaneidade aliada à sabedoria e criatividade infantis. Os Livros da Vida, conjunto de registos produzidos pelos alunos que, posteriormente, eram utilizados como recurso de ensino, traduziam o resultado deste ideário pedagógico.

A pedagogia centrista de Hrisch ${ }^{56}$ associa o declínio da qualidade das escolas às sucessivas revisões curriculares, em que se subordina objetivos e conteúdos à filosofia política e à agenda política-pedagógica. Partindo do pressuposto de que só se pode inovar a partir da conservação e transmissão dos conhecimentos, Hrisch, autor da obra The Schools We Need, em 1996, defende o papel significativo do currículo, pois este assegura, une e conserva o melhor que as gerações anteriores foram construindo.

Sizer $^{57}$, mentor da pedagogia essencialista, releva a importância da criação de uma cultura da escola que se norteia em princípios básicos (árbitros do clima da escola), tais como: o respeito pelos alunos, o

destacam-se: Os Sistemas Educativos dos Povos Culturais (1927), A Formação do Homem (1933) e Educação Política Nacional (1933).

${ }^{54}$ Alexander Sutherland Neill (1883 -1973): educador, escritor e fundador da escola Summerhill. Ficou famoso por defender a liberdade das crianças na educação escolar. ${ }^{55}$ Celestin Freinet (1896 - 1966): educador francês desenvolveu atividades hoje comuns, como as aulas-passeio e jornal de classe, e criou um projeto de escola moderna e democrática. Freinet inscreve-se, historicamente, entre os educadores identificados com a corrente da Escola Nova.

${ }^{56}$ Eric Donald Hirsch (1928): professor americano e crítico literário.

57 Theodore Ryland Sizer (1932 - 2009): professor norte-americano e um líder na reforma educacional. 
respeito pelos professores, a autodisciplina, a confiança mútua, a responsabilidade e a tolerância. A estrutura administrativa e pedagógica da escola assenta num misto de democracia representativa e de democracia participativa, ou seja, os alunos também são chamados a participar em várias decisões.

Muito semelhante à conceção libertária, a pedagogia institucional procura suprimir nos alunos a relação de dependência com o professor. $\mathrm{O}$ papel do mestre reduz-se ao apoio, à ajuda e animação do grupo, ou seja, este é somente um facilitador e age só quando é solicitado. A escola é considerada um microcosmo igualitário e um instrumento para a generalização da utopia autogestionária e igualitária a toda a sociedade. A avaliação e a planificação são refutadas por selecionarem e restringirem a criatividade.

Com os contributos e estudos do âmbito da psicologia, nomeadamente os estudos de condicionamento da aprendizagem de Pavlov (Arenilla et al, 20013), o modelo de ensino diretivo defende um ensino altamente estruturado e dirigido. Este modelo de ensino tem como base a teoria comportamentalista também denominada de modelo comportamentalista e modelo da aprendizagem social. Assente no princípio da operacionalidade dos objetivos de instrução, torna-se importante conceber o processo de ensino de uma forma individualizada que respeite os ritmos de aprendizagem dos alunos. Neste paradigma do estímulo-respostareforço, o professor deverá fazer uso de uma planificação e de uma avaliação rigorosas.

O modelo de ensino para a mestria criado por Benjamin Bloom ${ }^{58}$, também se baseia nas teorias comportamentalistas da aprendizagem, logo o processo de ensino e aprendizagem depende de uma planificação e avaliação rigorosas. Após os estudos efetuados pelo psicólogo americano John B. Carroll, considerou-se que os níveis de desempenho dependem da proporção entre o tempo real de aprendizagem e o tempo necessário à sua realização. Esta evidência leva a que se criem processos de

58 Benjamin Bloom: pedagogo e psicólogo norte-americano, nascido em 1913 e falecido em 1999, lecionou na Universidade de Chicago onde desenvolveu investigações sobre os processos de planificação e avaliação no ensino. Teve uma influência decisiva na área das ciências da educação ao propor uma taxionomia dos objetivos educacionais. De entre as suas obras pode-se destacar: Human Characteristics and School Learning e Taxonomy of Educational Objetives. Benjamin Bloom. In Infopédia [Em linha]. Porto: Porto Editora, 2003-2014. [Consult. 2014-0304]. Disponível em http://www.infopedia.pt/\$benjamin-bloom. 
remediação, tais como aulas complementares ou apoios pedagógicos acrescidos, de forma a conceder ao aluno o tempo realmente necessário para aprender.

O autor Gal (1976) clarifica que, dando mais ênfase ao domínio emocional do que ao domínio cognitivo, Carl Rogers ${ }^{59}$ criou o modelo de ensino não diretivo alicerçado no princípio de que a finalidade da educação é o crescimento da pessoa e não apenas a integração na sociedade. Neste modelo pedagógico, cujos conteúdos disciplinares são simplesmente instrumentos ao serviço do desenvolvimento da personalidade e das vocações, o aluno faz uma aprendizagem autónoma num ambiente livre, rodeado de relações humanas positivas e despojado de mecanismos de controlo, de recompensas e de castigos. O pedagogo assume o papel de psicoterapeuta.

No modelo da clarificação de valores (MCV), o professor assume-se como um facilitador de autoclarificação dos valores. Criado, nos anos 60, na sequência da publicação da obra Values and Teaching, dos autores Louis Raths, Marril Harmin e Sidney Simon, este modelo, influenciado pela psicanálise e pelas teorias personalistas, libertárias e não diretivas, tem como objetivo levar o aluno a tomar consciência dos seus valores através de um conjunto de estratégias/exercícios aplicados na sala de aula.

A aplicação do modelo curricular comunidade justa (MCJ), criado por Kohlberg $^{60}$, nos anos 70, inspirado na teoria do desenvolvimento

${ }^{59}$ Carl Ransom Rogers (1902-1987): psicólogo norte-americano que desenvolveu a Psicologia Humanista, também chamada de Terceira Força da Psicologia.

60 Lawrence Kohlberg (1927-1987): psicólogo norte-americano, formado em Psicologia na Universidade de Chicago com uma tese sobre o raciocínio moral nas crianças e adolescentes. Depois de ter sido assistente na universidade onde se doutorou, foi para Harvard onde desenvolveu um programa de formação no domínio do desenvolvimento humano.

Kohlberg apresenta uma teoria inovadora sobre o desenvolvimento moral baseada em estudos sobre crianças, adolescentes e adultos. Considera que o desenvolvimento moral se desenrola em seis estádios independentemente da cultura, grupo social ou país. Cada estádio apresentaria características próprias, estando relacionado com a idade e representando um sistema de organização mais compreensivo e qualitativamente diferente do estádio anterior.

De entre as suas obras pode-se destacar: Essays on Moral Development I, II and The Philosophy of Moral Development and the Psychology of Moral Development. Lawrence Kohlberg. In Infopédia [Em linha]. Porto: Porto Editora, 2003-2014. [Consult. 2014-03-15]. Disponível na www: <URL: http://www.infopedia.pt/\$lawrence-kohlberg>. 
cognitivo de Piaget, deveu-se ao facto de se verificar que o MCV era ineficaz. As tensões que resultavam em atos de violência dentro e fora da escola e as transformações sociais (mobilidade social, diversidade cultural, famílias monoparentais), remeteram, cada vez mais, a educação moral, que dantes era assegurada quer pela família e quer pela igreja, para uma das funções da escola. Visando fazer uma educação para os valores, aliam-se duas estratégias: os alunos são levados a participar na discussão de dilemas morais e a fazer parte da criação do governo democrático na escola. A também denominada cluster schools ou escola alternativa, onde tende a ser um lugar que prepara para o exercício da cidadania, apenas se diferencia da escola do ensino regular pela forma de participação dos alunos na vida da escola. É importante frisar que este organismo escolar só resulta com um número reduzido de alunos e professores e com o recurso a líderes educativos excecionalmente dedicados e competentes.

Associados à pedagogia crítica estão os autores Michael Apple ${ }^{61} \mathrm{e}$ Peter McLaren ${ }^{62}$ (este último tem como base autores como: Herbert Marcuse, Paulo Freire e Michel Foucault). Claramente firmado nos princípios marxistas, este modelo visa a "libertação" das minorias étnicas, sexuais e culturais que, até então, eram ignoradas pelo sistema político educativo. Desta forma, refuta-se a "cultura comum" ou "cultura canónica" e o "currículo canónico", pois, segundo os defensores (neomarxistas) desta corrente, a elevação dos padrões educacionais geram e legitimam desigualdades sociais.

Atualmente, século XXI, novos paradigmas societais e epistemológicos, emergem nesta nova dinâmica social em constante mudança influem na conceção que temos, hoje, do papel e da importância do professor e da escola.

Os autores Gasparin (2009) e André (2012) são unânimes ao salientarem que, perante esta conjuntura, o professor é ainda mais

${ }^{61}$ Michael W. Apple (1942): teórico da educação especializada em educação e poder, política cultural, a teoria curricular e pesquisa, ensino fundamental, e o desenvolvimento de escolas democráticas. Da sua numerosa obra destacam-se: Official Knowledge, Ideology and Curriculum, Education and Power e Teachers and Texts.

62 Peter McLaren (1948): professor e desenvolveu estudos sobre a pedagogia pósmoderna, a pedagogia critica e a educação multicultural. É autor e editor de quarenta e cinco livros e centenas de artigos académicos e capítulos. Da sua numerosa obra, destacam-se: Critical Multiculturalism, Critical Pedagogy and Predatory Culture, Critical Theory and Educational Research, Paulo Freire: A Critical Encounter e Politics of Liberation: Paths from Freire. 
necessário na medida em que, "quando se buscam mudanças efetivas nas salas de aula e na sociedade" (Gasparin, 2009, p. 1), se pensa logo no "mestre". As tecnologias são importantes e cada vez mais imprescindíveis na ação do professor. A escola é um dos reflexos e uma das respostas às necessidades da sociedade em que está inserida e, neste sentido, esta "nunca é neutra, mas sempre ideológica e politicamente comprometida" (p. 1).

Ressalva-se também o paradigma economicista, em que tudo é reduzido à condição de mercadoria. Neste contexto, as humanidades podem contribuir para reverter esses valores economicistas em valores culturais ou valores identitários. Integrar no currículo o estudo da história, da geografia, das artes, das línguas, da filosofia, das ciências da comunicação pode mudar o modelo mercantilista. Uma formação humanística assegura as referências socioculturais e contraria a tendência atual para o consumo, para o efémero, para o descartável, para as modas de pensamento, de opinião em permanente mutabilidade, modelo social que Zygmunt Bauman denominou por "modernidade líquida" 63 ou sociedade líquida, sociedade sem raízes, fluída.

Em suma, Barroso (citado em Martins, 2013, p. 22) faz referência a três futuros possíveis para o processo de escolarização: a hiperescolarização, a desescolarização e a refundação, todos eles potenciados pela utilização das Tecnologias da Informação e Comunicação (TIC). Sendo a hiperescolarização relacionada com o reforço da escola homogénea; a desescolarização, princípio defendido por Illich que defende o fim da escola, pois o ato de educar compete aos pais, à comunidade e à livre iniciativa e, por último, a refundação ${ }^{64}$, segundo o investigador, o mais desejável. Este movimento pedagógico, conhecido por Educação Nova, desenvolvido nos inícios do século XX, defende o desenvolvimento das competências individuais, da aprendizagem interativa, da escola criativa e ativa, apostando na autonomia do aluno.

\footnotetext{
${ }^{63}$ Modernidade líquida: o filósofo e sociólogo polonês Zygmunt Bauman escreve a obra intitulada Modernidade Líquida, em 2001, uma reflexão da sociedade atual: tudo é volátil, as relações humanas não são mais tangíveis e a vida em conjunto, familiar, de casais, de grupos de amigos, de afinidades políticas e assim por diante, perde consistência e estabilidade.

${ }^{64}$ Refundação: o termo corresponde, também, à designação do programa aprovado, em 2013, pela Assembleia da República francesa para preparar a escola para a era digital - La refondation de l'École.
} 
Por fim, verifica-se que todo o processo de transformação, que se almeja para a escola de hoje, só é possível se os diversificados esforços, de forma dialogante, reflexiva, consciente e sustentável, convergirem numa educação à medida de cada aluno, baseada nos princípios da equidade, da igualdade de oportunidades e da inclusão social.

\section{BIBLIOGRAFIA}

André, J. M. (2012). Multiculturalidade, Identidades e Mestiçagem: o Diálogo Intercultural nas Ideias, na Política, nas Artes e na Religião. Coimbra: Palimage.

Arenilla, L., Gossot, B., Rolland, M. C. \& Roussel, M. P. (2013).

Dicionário de Pedagogia (2. ${ }^{\mathrm{a}}$ ed.). Lisboa: Instituto Piaget.

Aristóteles (2000). Tratado da Política (2. ${ }^{a}$ edição). Mem Martins: Europa América.

Damião, H. (2010). A (In)Dispensabilidade de Ensinar. In $O$ Valor de Educar, o Valor de Instruir (pp. 77-97). Colecção Questões-Chaves da Educação. Lisboa: Fundação Francisco Manuel Santos.

Gal, R. (1979). História da Educação. Lisboa: Editorial Veja.

Garin, E. (1972). O Renascimento, História de uma Revolução Cultural. Porto: Editora Telos.

Gasparin, J. L. (2009). Uma Didática para a Pedagogia HistóricoCrítica (4a. ed. rev. e ampl. Coleção Educação Contemporânea). Campinas - SP: Autores Associados.

Marques, R. (2001). História Concisa da Pedagogia. Lisboa: Plátano Editora.

Mautner, T.(Dir.) (2010). Dicionário de Filosofia. Lisboa: Edições 70.

Mialaret, G., \& Vial, J. (1985). História Mundial da Educação I. Coleção: Biblioteca da Educação. Porto: Rés-Editora.

Morus, T. (1994). A Utopia. Lisboa: Guimarães Editores. Platão (2003). Fédon (2. ${ }^{a}$ edição). Porto: Porto Editora.

Martins, C. F. (2013, 1 setembro). Quando a Escola Deixar de Ser uma Fábrica de Alunos. In Revista 2, 21-24. Consultado em 01/09/2013 de http://www.publico.pt/temas/jornal/quando-a-escola-deixar-de-seruma-fabrica-de-alunos-27008265 